\title{
RNA Interference: A Promising Approach for the Treatment of HBV Infection
}

\author{
Cornelius Arome 0matola* \\ Department of Virology, University of Ibadan, Nigeria
}

Submission: April 11, 2018; Published: May 24, 2018

*Corresponding author: Department of Virology, University of Ibadan, Nigeria, Email: omatolac@gmail.com

\begin{abstract}
Hepatitis B viral infection and associated sequelae is a public health concern as it is associated with high morbidity and mortality globally. The treatment modality currently available for patients with chronic condition cannot clear the viral DNA from infected hepatocytes and are associated with serious side effects and high rate of resistance. Thus, development of alternative therapeutic intervention with high rate of viral clearance, fewer side effects and that can target conserved regions of HBV genome remains a priority. Interestingly, RNA interference-based drugs have proven to be a promising therapeutic candidates and this article therefore reviews some of the potential benefits and how if refined can override current therapeutic hurdles against HBV.
\end{abstract}

Abbreviations: siRNA: Small Interfering RNA; cccDNA: Covalently Closed Circular DNA; NAG-MLP: N-acetyl Galactosamine Melitine-like Peptide; NUCs: Nucleoside Analogs; RNAI: RNA Interference

\section{Introduction}

Hepatitis B virus (HBV) infection is global health problem with over 350 million HBV carriers worldwide and over one million deaths occurring annually due to HBV-induced liver diseases [1]. Currently, HBV infection is treated with immunomodulatory agents (e.g. IFN- $\alpha$ ) and nucleoside analogs such as lamivudine which are only partially effective [2]. Drawbacks of current therapies include Low efficacy, severe side effects and occurrence of resistance due to HBV mutations $[1,3]$. In view of the aforementioned challenges posed by current treatment regimen, there is the need for a better treatments option that can suppress viral replication within short duration, have high cure rates and fewer side effects [3,4]. RNA interference (RNAi) is a process by which small interfering. RNA (siRNA) with specific sequences induce silencing of homologous genes by binding to their complementary mRNA and inducing the elimination of the mRNA [5]. RNAi has shown antiviral effect against HBV, Hepatitis C virus (HCV), Human Papillomavirus (HPV) and Human immunodeficiency virus (HIV) [5,6]. Unlike HCV and HIV, the small size genome and presence overlapping reading frames (ORFs) in HBV makes it more susceptible to inhibition by RNAi $[2,7,8]$.

Attributes of RNAi-Based Therapy

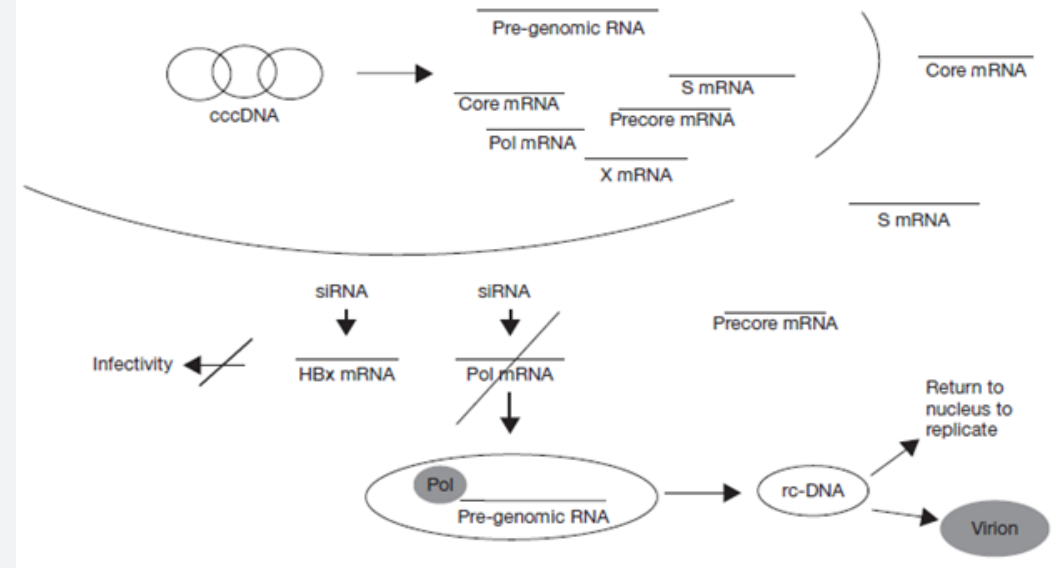

Figure 1: HBV Targets For siRNA Based Therapy. 


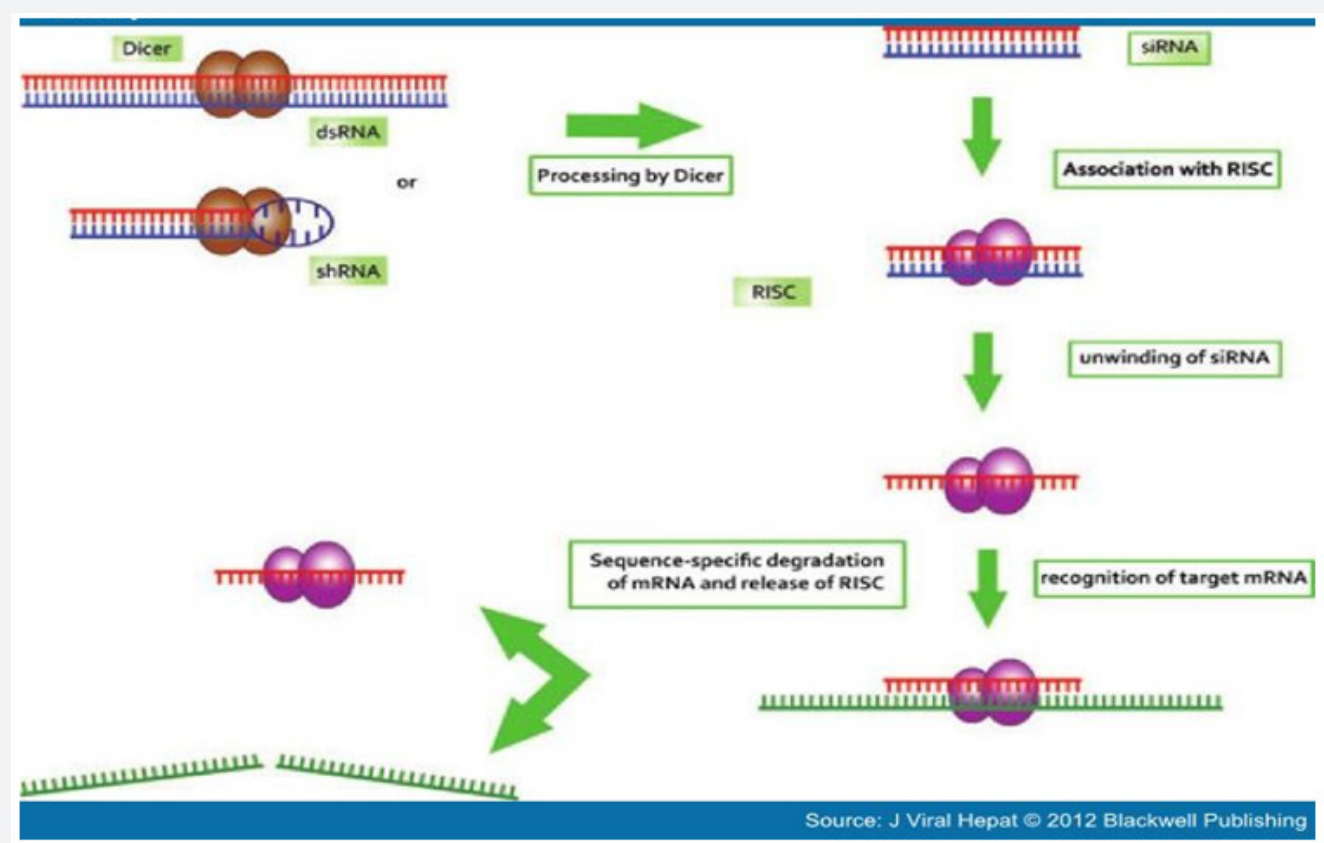

Figure 2: Mechanism of RNAi.

siRNA mediated inhibition of gene expression does not require any viral DNA replication [3,4]. siRNA combinations have ability to target conserved regions of the viral genome $[9,10]$. Reduction of HBV DNA from infected hepatocyte [3]. Because RNAi-based drugs can be expressed from introduced genes, they offer the possibility for a sustained therapeutic response [11]. siRNA mediated inhibition is specific and potent $[3,9,11]$ (Figure $1,2)$.

\section{Methods of siRNA Synthesis}

Chemical synthesis: This involves the production of sense and antisene strands, annealing of the strands, adding stable chemical entities and 2 nt overhangs at $3^{\prime}$ end.

Ambion (Huston, TX) recommended the following guidelines for designing siRNAs: Beginning with the AUG of the target gene transcript, search downstream for AA dinucleotide sequences, each AA and the $3^{\prime}$ adjacent 19 nt are potential siRNAs; blast the potential sequences against the species-specific genome database to eliminate cross-silencing phenomenon with nontarget genes [12].

a. Web-based software called siDirect algorithm incorporated the Ambion guidelines above for designing siRNAs [3]

b. Endogenous vector Expression of Anti-HBV shRNA which involves the use of Plasmid to express shRNA that are converted into siRNA in cells $[13,14]$.

\section{Delivery Strategies}

a. Cationic liposome: This contains lipid with positively charged group (e.g cholesteryl spermine) that form complexes with siRNA $[15,16]$. b. Cationic polymer: like liposome, also form complexes with the negatively charged phosphate groups of the siRNA e.g. NAG-MLP [17].

\section{Challenges}

Delivery of the siRNA into the target organ $[3,10]$.

Bioavailability and stability of siRNAs [18].

\section{What has been done to address these hurdles...}

Use of specific delivery methods-such as cholesteryl spermine conjugation, formulation into liposomes and complexing with cationic polymers e.g NAG-MLP (Figure 3,4) [11,16]. In vivo stability of siRNA has been improved via chemical modification of backbone with 2'F, 2'O-Methyl, and 2'H to substitute 2'-OH residues required for nuclease activity $[19,20]$.

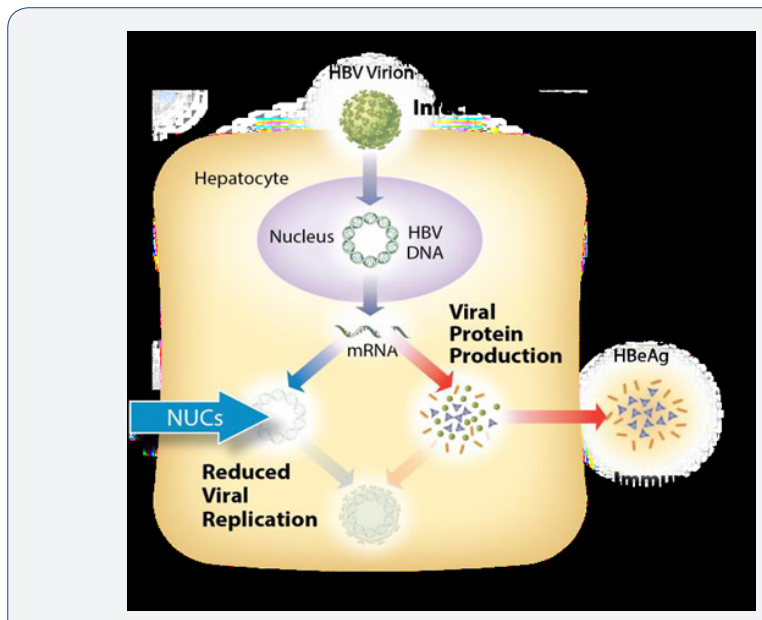

Figure 3: RNAI-Based Therapeutic Candidates.

ARC-520: it uses a different mechanism than NUCs. 


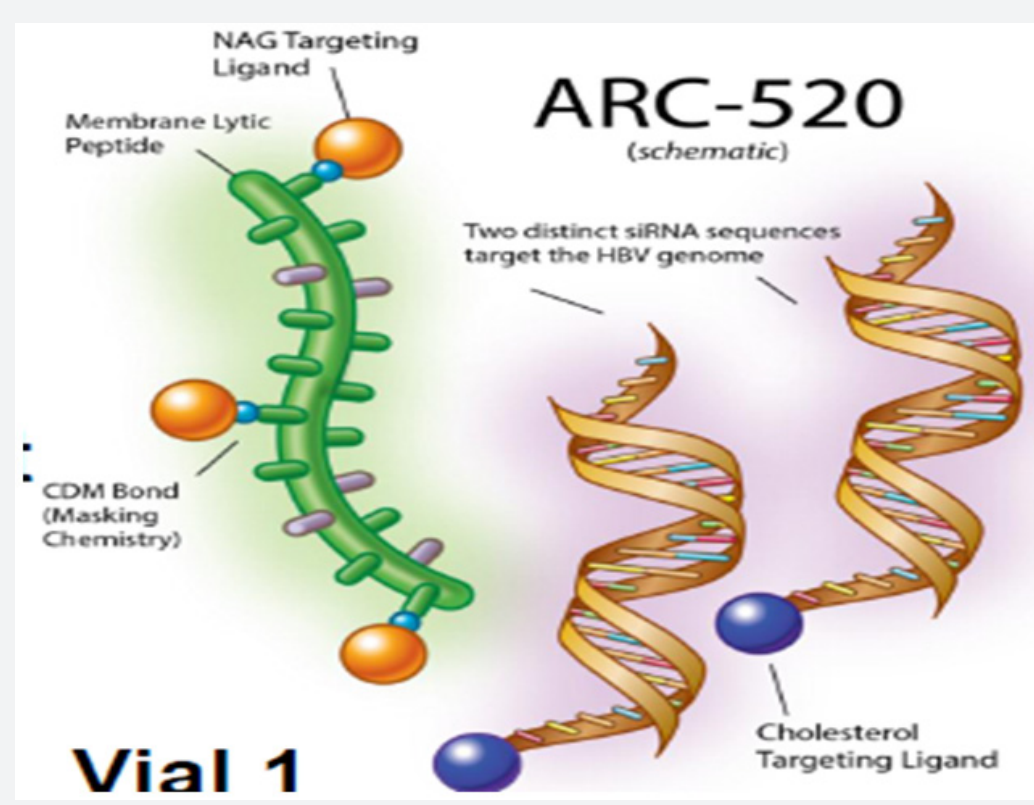

Figure 4: Source: Schluep [2].

\section{ARC 520 Results}

A single low dose of ARC-520 resulted in > 95\% reduction of HBV RNA, proteins (eg.HBeAg and HBsAg) and viral DNA with long duration of effect in mouse and chimpanzee models of HBV infection (Figure 5). In chimpanzee, Levels of HBV DNA, HBeAg , HBsAg only return to baseline after 43,43, and 71 days respectively of dosing (Figure 5) [2]. ARC-520 has gone through phase-1-clinical trials. Results of a phase 1 from first-in-human safety and tolerability studies conducted among 36 patients with chronic HBV showed that the drug was reasonably safe and well tolerated. No dropouts for any reason and no serious adverse events [2].
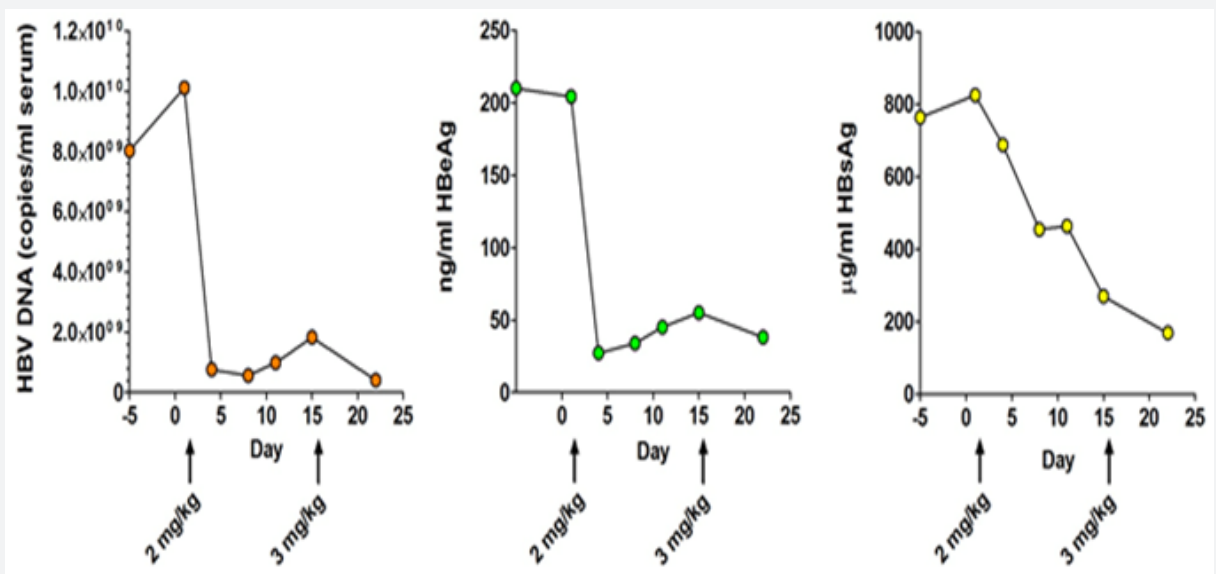

Figure 5: Highly effective at reducing antigenemia in Chimpanzee with chronic HBV.

\section{Conclusion and Prospects for Clinical Application}

The use of RNAi pathway as a new approach in antiviral drug discovery is promising as the genetic distance between mammalian and HBV genome represents an advantage in minimizing offtarget hits and reducing possible side effects [21]. The ability of RNAI to effectively and durably halt viral protein production can lead to complete HBsAg loss and conversion to seronegative status; eliminates long treatments and patient compliance issues [2]. Although, RNAi-based therapeutic intervention against HBV infection has shown to be promising, improvements in safety and efficacy of delivery methods however remained important objectives for future studies to adress [22-27].

\section{References}

1. Wu HL, Huang LR, Huang CC, Lai HL, Liu CJ, et al. (2005) RNA interference-mediated control of hepatitis $\mathrm{B}$ virus and emergence of resistant mutant. Gastroenterology 128(3): 708-716.

2. Robert GG, Satishchandran C, Michael Y, Catherine P (2011) RNA interference and its potential applications to chronic HBV treatment: 
results of a phase 1 safety and tolerability study. Antiviral therapy 16(4): 547-554.

3. Uprichard SL, Boyd B, Althage A, Chisari FV (2005) Clearance of hepatitis $B$ virus from the liver of transgenic mice by short hairpin RNAs. Proc Natl Acad Sci USA 102(3): 773-778.

4. Chen Y, Cheng G, Mahato RI (2008) RNAi for treating hepatitis B viral infection. Pharm Res 25(1): 72-86.

5. Bryan C (2013) Arrowhead reduces 90 percent of hepatitis B antigens in chimpanzee study.

6. Fire A, Xu S, Montgomery MK, Kostas SA, Driver SE, et al. (1998) Potent and specific genetic interference by double-stranded RNA in Caenorhabditis elegans. Nature 391(6669): 806-811.

7. Coburn GA, Cullen BR (2002) Potent and specific inhibition of human immunodeficiency virus type 1 replication by RNA interference. J Virol 76(18): 9225-9231.

8. McCaffrey AP, Nakai H, Pandey K, Huang Z, Salazar FH, et al. (2003) Inhibition of hepatitis $B$ virus in mice by RNA interference. Nat Biotechnol 21(6): 639-644.

9. Sun D, R"osler C, Kidd Ljunggren K, Nassal M (2010) Quantitative assessment of the antiviral potencies of 21 shRNA vectors targeting conserved, including structured, hepatitis B virus sites. J Hepatol 52(6): 817-826

10. Wilson R, Purcell D, Netter HJ, Revill PA (2011) Does RNAi provides new hope for the treament of chronic HBV infection? Antiviral therapy 14(7): 879-889.

11. Marc SW, Patrick A (2010) Progress in the use of RNA interference as a therapy for chronic hepatitis B virus infection. Genome Medicine 2:28.

12. Milhavet O, Gary DS, Mattson MP (2003) RNA interference in biology and medicine. Pharmacol Rev 55(4): 629-648.

13. Brummelkamp TR, Bernards R, Agami R (2002) A system for stable expression of short interfering RNAs in mammalian cells. Science 296(5567): 550-553.

14. Paddison PJ, Caudy AA, Hannon GJ (2002) Stable suppression of gene expression by RNAi in mammalian cells. PNAS 99(3): 1443-1448.

15. Mahato RI, Rolland A, Tomlinson E (1997) Cationic lipid-based gene delivery systems: pharmaceutical perspectives. Pharm Res 14(7): 853859.
16. Morrissey DV, Lockridge JA, Shaw L, Blanchard K, Jensen K, et al. (2005) Activity of stabilized short interfering RNA in a mouse model of hepatitis B virus replication. Hepatology 41(6): 1349-1356.

17. Han SO, Mahato RI, Sung YK, Kim SW (2000) Development of biomaterials for gene therapy. Mol Ther 2(4): 302-317.

18. Ronald PR (2008) Virus meets RNAi. Symposium on Antiviral Applications of RNA Interference. EMBO Rep 9(8): 725-729.

19. Shiraishi T, Hamzavi R, Nielsen PE (2008) Subnanomolar antisense activity of phosphonate-peptide nucleic acid (PNA) conjugates delivered by cationic lipids to HeLa cells. Nucleic Acids Res 36(13): 4424-4432.

20. Watts JK, Choubdar N, Sadalapure K, Pinto BM, Damha MJ (2007) 2'-fluoro-4'-thioarabino-modified oligonucleotides: conformational switches linked to siRNA activity. Nucleic Acids Res 35(5): 1441-1451.

21. Zhang YL, Cheng T, Cai YJ (2010) RNA Interference inhibits hepatitis $B$ virus of different genotypes in vitro and in vivo. BMC Microbiology. 10: 214 .

22. Xuan B, Qian Z, Hong J, Huang W (2006) EsiRNAs inhibit Hepatitis B virus replication in mice model more efficiently than synthesized siRNAs. Virus Res 118(1-2): 150-155.

23. Zhang XN, Xiong W, Wang JD, Hu YW, Xiang L, Yuan ZH (2004) siRNAmediated inhibition of HBV replication and expression. World J Gastroenterol 10(20): 2967-2971.

24. Davis ME, Zuckerman JE, Choi CH, Seligson D, Tolcher A, et al. (2010) Evidence of RNAi in humans from systemically administered siRNA via targeted nanoparticles. Nature 464: 1067-1070.

25. Hoofnagle JH, di Bisceglie AM (1997) The treatment of chronic viral hepatitis. N Engl J Med 336(5): 347-356.

26. Lau DT, Everhart J, Kleiner DE, Park Y, Vergalla J, et al. (1997) Long-term follow-up of patients with chronic hepatitis B treated with interferon alpha. Gastroenterology 113(5): 1660-1667.

27. Yao G, Wang B, Cui Z (1999) Long-term effect of lamivudine treatment in chronic hepatitis B virus infection. Zhonghua Gan Zang Bing Za Zhi $7(2): 80-83$.

28. Verma IM, Somia N (1997) Gene therapy-promises, problems and prospects. Nature 389(6648): 239-242.

Your next submission with Juniper Publishers will reach you the below assets

- Quality Editorial service

- Swift Peer Review

- Reprints availability

- E-prints Service

- Manuscript Podcast for convenient understanding

- Global attainment for your research

- Manuscript accessibility in different formats

( Pdf, E-pub, Full Text, Audio)

- Unceasing customer service

Track the below URL for one-step submission

https://juniperpublishers.com/online-submission.php 